\title{
Up-Regulation of Inducible Nitric Oxide Synthase by Relaxin in Rat Coronary Endothelial Cells is Not Mediated by Proinflammatory Cytokines
}

\author{
Silvia Nistri ${ }^{1}$, Tiziana Persichini ${ }^{2}$, Chiara Sassoli ${ }^{1}$, Marco Colasanti ${ }^{2}$ and Daniele Bani ${ }^{*}, 1$ \\ ${ }^{I}$ Department of Anatomy, Histology \& Forensic Medicine, Section of Histology. University of Florence. Viale G. \\ Pieraccini 6. I-50139 Florence, Italy \\ ${ }^{2}$ Department of Biology, University "Roma Tre”, Viale G. Marconi 446. I-00146 Rome, Italy
}

\begin{abstract}
Relaxin, best known for its reproductive effects can be also viewed as a cardiovascular hormone. Its action includes a marked increase in coronary blood flow, exerted through the up-regulation of inducible nitric oxide (NO) synthase (NOS II) and NO production in vascular endothelial and smooth muscle cells. This effect seems to involve NF- $\kappa \mathrm{B}$, a classical transcription factor controlling NOS II induction by proinflammatory cytokines. The present study was designed to clarify the mechanisms underlying the relaxin-induced up-regulation of NOS II gene in endothelial cells. Rat coronary endothelial (RCE) cells were grown for $30 \mathrm{~min}, 2,6$ and $12 \mathrm{~h}$ in the absence or presence of $60 \mathrm{ng} / \mathrm{ml}$ porcine relaxin. Time-course analysis of the expression of NOS II and the proinflammatory cytokines IL-1 $\beta$ and TNF $\alpha$ was performed. Relaxin induced the expression of NOS II transcript and protein at all these time points. No correlation was observed with the expression profiles of the genes for the assayed cytokines: IL- $1 \beta$ expression showed a first peak at 30 min. followed by a decline and a second peak at $12 \mathrm{~h}$, whereas faint TNF- $\alpha$ expression was only detected at $2 \mathrm{~h}$. Relaxin retained the ability to induce NOS II transcript and to generate NO even in the presence of neutralizing anti- IL1 $\beta$ and/or anti-TNF- $\alpha$ antibodies. The current findings suggest that the induction of NOS II by relaxin in coronary endothelial cells is a direct effect of this hormone and does not depend on a primary cytokine-mediated pathway that eventually results in $\mathrm{NF}-\kappa \mathrm{B}$ activation and NOS II induction.
\end{abstract}

\section{INTRODUCTION}

Relaxin, a peptide hormone of the insulin-IGF superfamily best known for its effects on reproduction $[1,2]$, has been recently validated as a cardiovascular hormone [3-6], as it can activate specific receptors on the heart and the blood vessels $[7,8]$. The effects of relaxin on the cardiovascular system include a marked increase in coronary blood flow $[9,10]$, which involves the activation of the endogenous production of the gaseous free radical and potent vasodilator nitric oxide (NO) by vascular endothelial and smooth muscle cells in vitro [11-13]. In these studies, relaxin was shown to promote endogenous NO generation by an up-regulation of inducible nitric oxide synthase (NOS II). In particular, in endothelial cells from both rat coronary vessels (RCE) and human umbilical vein (HUVEC), treatment with relaxin caused a de novo transcription of NOS II gene, as judged by the increased amount of NOS II mRNA and protein [12,13]. These effects were inhibited by dexamethasone [12] or curcumin [13], potent inhibitors of the transcription factor NF$\kappa B[14,15]$, thus suggesting the involvement of NF- $\kappa B$ in the response of endothelial cells to relaxin. In fact, $N F-\kappa B$ is known to bind to the NOS II gene promoter [16] and to be involved in the induction of NOS II caused by cytokines and bacterial lipopolysaccharide (LPS) $[14,16]$.

*Address correspondence to this author at the Department of Anatomy, Histology \& Forensic Medicine, Section of Histology. University of Florence. Viale G. Pieraccini 6. I-50139 Florence, Italy;

E-mail: daniele.bani@unifi.it
However, it remains to be clarified whether the reported induction of NOS II by relaxin, observed upon the addition of this hormone to the endothelial cell cultures, is a direct effect or may rather follow the primary activation of a cytokine-mediated pathway that eventually results in NF- $\mathrm{KB}$ activation and NOS II induction. The present study was designed to address this issue.

\section{MATERIALS AND METHODS}

\section{Isolation and Culture of Rat Coronary Endothelial (RCE) Cells}

RCE cells were isolated from hearts of 2-3-month old Wistar rats, as described previously [17]. Animal handling was done in compliance with the recommendations of the European Economic Community (86/609/CEE) for the care and use of laboratory animals and with the principles of Good Laboratory Practice. The experiment was approved by the animal care committee of the University of Florence. Briefly, after enzymatic digestion of heart tissue fragments, the recovered cells were stirred for $30 \mathrm{~min}$ at $37^{\circ} \mathrm{C}$ in the presence of $10 \mathrm{mg} / 50 \mathrm{ml}$ trypsin, centrifuged, resuspended in $15 \mathrm{ml}$ of culture medium (see below), and plated. After $4 \mathrm{~h}$, cells were washed twice and grown until they were confluent (5-6 days). M199 containing 20\% foetal bovine serum (FBS), $250 \mathrm{U} / \mathrm{ml}$ penicillin $\mathrm{G}, 0.625 \mu \mathrm{g} / \mathrm{ml}$ amphotericin and $250 \mu \mathrm{g} / \mathrm{ml}$ streptomycin, was used as culture medium. By this method, RCE cells are $97 \%$ pure and express typical endothelial markers [17]. RCE cells were used at the $1^{\text {st }}$ passage in culture. 
Media, sera and reagents for cell culture were from Sigma-Aldrich (Milan, Italy) and Gibco BRL (Paisley, Scotland, UK). Cell culture plastic ware was purchased from Costar (Corning Costar Co., Costar Italia, Milan, Italy). Highly purified porcine relaxin (2500 to $3000 \mathrm{U} / \mathrm{mg}$ ) was the generous gift of Dr. O.D. Sherwood. The relaxin preparation used was endotoxin-free, as assessed by the Limulus amebocyte lysate assay (E-toxate, Sigma-Aldrich).

\section{Evaluation of NOS II and Cytokine mRNA Expression by RT-PCR}

For time-course analysis of the expression of NOS II, IL$1 \beta$ and TNF $\alpha$ transcripts, RCE cells seeded in $25 \mathrm{~cm}^{2}$ culture flasks were grown for $30 \mathrm{~min}, 2 \mathrm{~h}, 6 \mathrm{~h}$ and $12 \mathrm{~h}$ in the absence (controls) or presence of $60 \mathrm{ng} / \mathrm{ml}$ relaxin. This concentration of the hormone was similar to that found previously to induce NOS II in RCE cells [12]. At the end of the experiments, total RNA was extracted using Trizol Reagent (Gibco-BRL) according to the manufacturer's protocol and quantified spectrophotometrically at a $260-\mathrm{nm}$ wave length. Then, $1 \mu \mathrm{g}$ of total RNA was reverse-transcribed and amplified with SuperScript ${ }^{\mathrm{TM}}$ One-Step ${ }^{\mathrm{TM}}$ RT-PCR System (Invitrogen, Groningen, The Netherlands) in a total volume of 50 $\mu 1$. After cDNA synthesis for $30 \mathrm{~min}$ at $55^{\circ} \mathrm{C}$, the samples were pre-denaturated for $2 \mathrm{~min}$ at $94^{\circ} \mathrm{C}$; the first-strand cDNA was subjected to 35 cycles of PCR performed at $94^{\circ} \mathrm{C}$ for $15 \mathrm{sec}, 55^{\circ} \mathrm{C}$ for $30 \mathrm{sec}$ (NOS II, IL-1 $\beta$ ) and $62^{\circ} \mathrm{C}$ for 30 $\sec (\mathrm{TNF}-\alpha)$, and $72^{\circ} \mathrm{C}$ for $1 \mathrm{~min}$; the final extension step was performed at $72^{\circ} \mathrm{C}$ for $5 \mathrm{~min}$. Internal standards for quantification of NOS II and cytokine cDNAs were generated by amplifying GAPDH mRNA performing 35 cycles of the following steps: $94^{\circ} \mathrm{C}$ for $15 \mathrm{sec}, 55^{\circ} \mathrm{C}$ for $30 \mathrm{sec}$ and $72^{\circ} \mathrm{C}$ for $1 \mathrm{~min}$.

The following sets of primers were used: NOS II sense, 5'-GCT ACA CTT CCA ACG CAA CA-3'; antisense, 5'GGC GAA GAA CAA TCC ACA AC-3'; IL-1 $\beta$ sense, 5'AAA AGC TTG GTG ATG TCT GG-3'; antisense, 5'-TTT CAA CAC GCA GGA CAG G-3'; TNF- $\alpha$ sense, 5'-GAG CTG AGA GAT AAC CAG CTG GTG-3'; antisense, 5'CAG ATA GAT GGG CTC ATA CCA GGG-3'; GAPDH sense, 5'-CCA TGG AGA AGG CTG GGG-3'; antisense, 5'-CAA AGT TGT CAT GGA TGA CC-3'. The resulting PCR products were analyzed on a $2 \%$ agarose gel using appropriate base pair markers to verify the requires size of the final PCR products. Bands were quantified by densitometric analysis using Scion Image Beta 4.0.2 image analysis program (Scion Corp., Frederick, MD, USA). Values are the mean $( \pm \mathrm{SEM})$ of 3 separate experiments.

\section{Western Blotting for NOS II Protein}

RCE cells seeded into $75 \mathrm{~cm}^{2}$ flasks were grown for 30 $\min , 2 \mathrm{~h}, 6 \mathrm{~h}$ and $12 \mathrm{~h}$ in the absence (controls) or presence of relaxin $(60 \mathrm{ng} / \mathrm{ml})$. Cells were then detached in trypsin/EDTA, washed thoroughly and placed in cold lysis buffer of the following composition: $20 \mathrm{mM}$ Tris/ $\mathrm{HCl} \mathrm{pH}$ 7.4, $10 \mathrm{mM} \mathrm{NaCl}, 1.5 \mathrm{mM} \mathrm{MgCl}_{2}, 1.3 \mathrm{mM} \mathrm{Na}_{2}$ EDTA, 1 $\mathrm{mM}$ dithiotreitol (DTT), $1 \mathrm{mM}$ phenylmethylsulfonyl fluoride (PMSF), 0.25\% Triton X-100, $20 \mu \mathrm{g} / \mathrm{ml}$ Leupeptin, 1 $\mu \mathrm{g} / \mathrm{ml}$ Pepstatin, $1 \mathrm{mg} / \mathrm{ml}$ Pefabloc SC, $2.5 \mu \mathrm{g} / \mathrm{ml}$ Aprotinin. Upon centrifugation at $17,000 \mathrm{~g}$ at $4{ }^{\circ} \mathrm{C}$, the supernatants were collected and the total protein content was measured spectrophotometrically using a micro-BCA protein assay kit
(Pierce, Rockford, IL). The samples, each containing $35 \mu \mathrm{g}$ of total proteins, were electrophoresed by SDS-PAGE and blotted onto nitrocellulose membranes (Amersham). After thorough washings in PBS added with $0.1 \%$ Tween 20 (TPBS), the membranes were treated with albumin 5\% in $\mathrm{T}$ PBS to block aspecific binding sites and incubated overnight at $4^{\circ} \mathrm{C}$ under stirring with rabbit polyclonal antibodies against NOS II (Alexis, Läufelingen, Switzerland), diluted 1: 50,000 in T-PBS added with $1 \%$ bovine serum albumin. Immune reaction was revealed by peroxidase-labeled goat anti-rabbit antibodies (Vector, Burlingame, CA), diluted 1: 10,000 in T-PBS with $1 \%$ bovine serum albumin and applied to the membranes for 1 hour at room temperature under stirring, followed by 1-min incubation with the chemiluminescent substrate ECL (Amersham, Buckinghamshire, UK) and exposure to high-sensitivity photographic film (Biomax ML, Kodak, Rochester, NY).

\section{Evaluation of the Role of IL-1 $\beta$ and TNF $\alpha$ on the Re- laxin-Induced NOS II mRNA Expression}

In order to clarify the role of IL-1 $\beta$ and TNF $\alpha$ on the relaxin-induced expression of NOS II, RCE cells were grown for $2 \mathrm{~h}$ in medium added with $60 \mathrm{ng} / \mathrm{ml}$ relaxin in the presence of excess concentrations of neutralizing goat polyclonal antibodies anti-IL-1 $\beta$ (R\&D Systems, Minneapolis, $\mathrm{MN} ; 4 \mu \mathrm{g} / \mathrm{ml})$, anti-TNF $\alpha$ (R\&D; $1.8 \mu \mathrm{g} / \mathrm{ml})$ or a mixture of both, according to manufacturer's instructions. As controls, RCE cells treated with nonimmune goat $\gamma$-globulins were used. At the end of the experiments, total RNA was extracted and NOS-II mRNA expression was evaluated as described above.

\section{Evaluation of NO Production}

This step was performed by measuring the accumulation of nitrites, the stable end-products of NO, in the supernatant of RCE cells. Cells were seeded into 24 -well plates at density of $5 \times 10^{4}$ cells/well, allowed to grow to subconfluence and then incubated for $2 \mathrm{~h}$ in the absence (controls) and presence of relaxin $(60 \mathrm{ng} / \mathrm{ml})$, alone or together with the neutralizing antibodies anti-IL-1 $\beta$, anti-TNF $\alpha$ or a mixture of both, at the above noted concentrations. The amount of nitrites was determined spectrophotometrically by the Griess reaction adapted for a 96-well plate reader [12]. In brief, $100 \mu \mathrm{l}$ of sample were added to $100 \mu$ of Griess reagent ( $1 \%$ sulfanilamide and $0,1 \% \mathrm{~N}$-(1-naphtyl)ethylendiamine in $5 \%$ phosphoric acid). The optical density at a wavelength of 546 nm was measured with a Bio Rad 550 micro plate reader. Nitrite concentrations in the supernatants were calculated by comparison with standard concentrations of $\mathrm{NaNO}_{2}$ dissolved in culture medium. The reported values are the mean $( \pm \mathrm{SEM})$ of 3 separate assays.

\section{RESULTS}

Time-course analysis of NOS II mRNA and protein shows that relaxin $(60 \mathrm{ng} / \mathrm{ml})$ induced the functional expression of NOS II gene at all the time points assayed, transcripts and protein being already detectable at $30 \mathrm{~min}$, attaining the climax at $2 \mathrm{~h}$, and declining slowly at the longer times (Fig. 1A,B). The untreated controls showed no detectable NOS II mRNA and protein expression. GAPDH, assumed as control invariant gene, did not change its levels of mRNA transcription upon relaxin treatment, at any time assayed (Fig. 1C). 
IL-1 $\beta$ expression in response to relaxin at the noted concentration showed a first peak at $30 \mathrm{~min}$. followed by a decline and a second peak at $12 \mathrm{~h}$ (Fig. 2). Faint TNF- $\alpha$ expression was only detected at $2 \mathrm{~h}$ (Fig. 3). Densitometric analysis of the PCR bands gave a quantitative confirmation to the visual observations (Fig. 4).

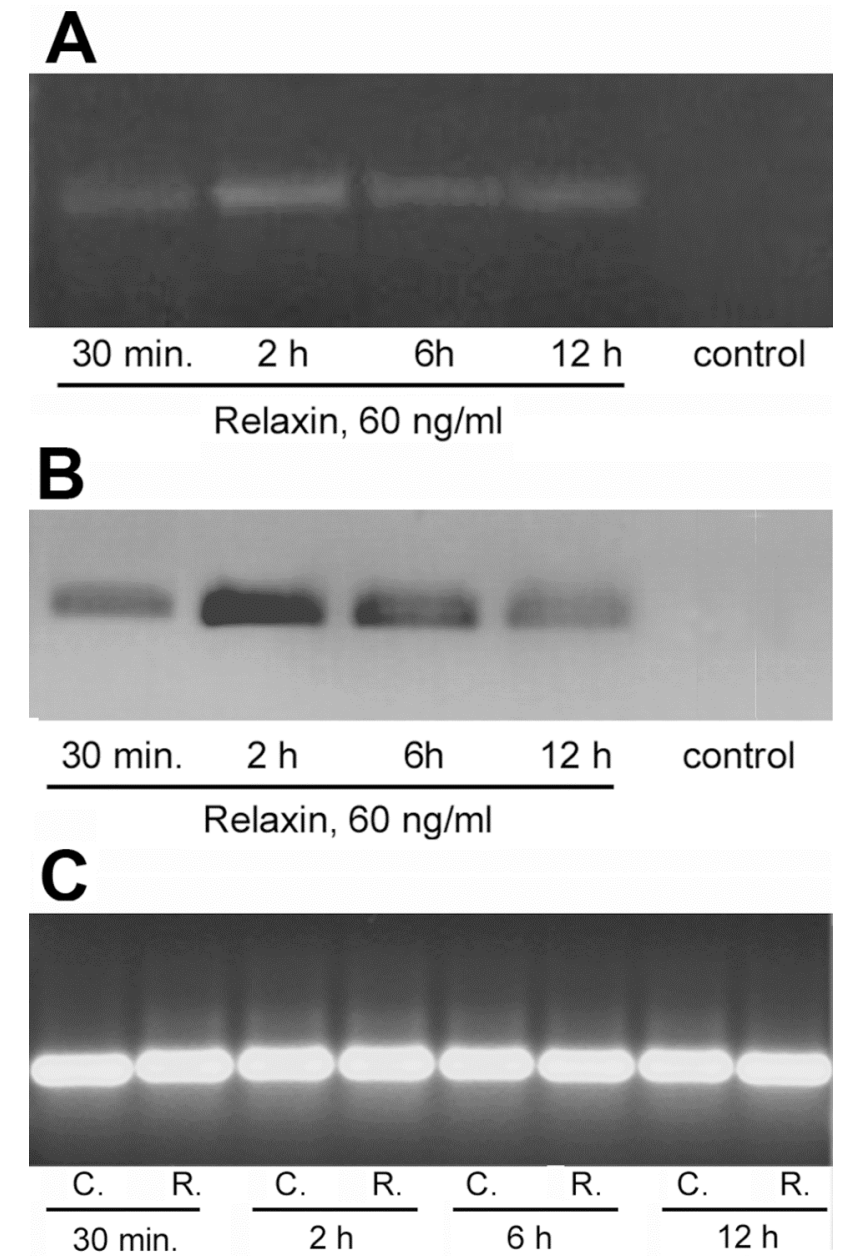

Fig. (1). Time-course of NOS II PCR amplification products (A) and protein expression (B) in RCE cells stimulated or not with relaxin. The amplicons for GAPDH (C), assumed as control invariant gene, show no changes in the different experimental groups. $\mathrm{C}$ : control cultures; R: cultures treated with relaxin $(60 \mathrm{ng} / \mathrm{ml})$.

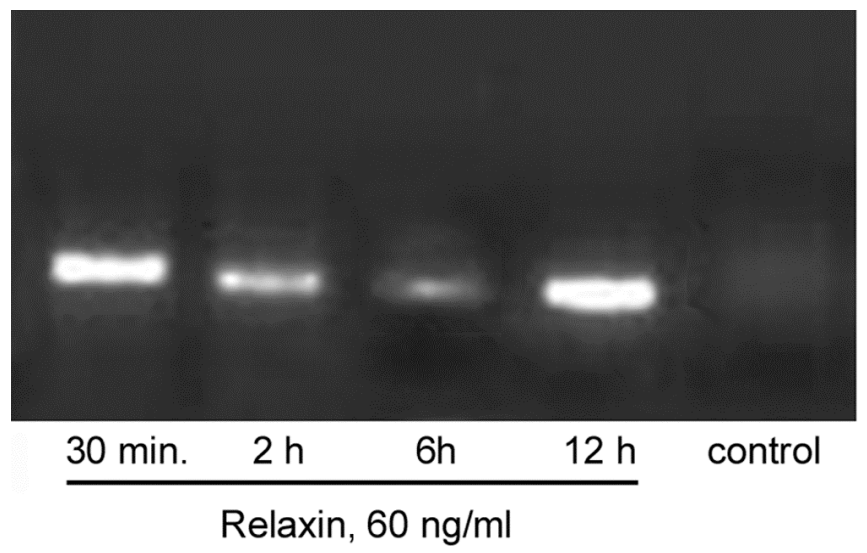

Fig. (2). Time-course of IL-1 $\beta$ PCR amplification products upon stimulation of RCE cells with relaxin at the noted concentration.
Despite the time course analysis showed no correlation between gene expression of NOS II, and of the cytokines

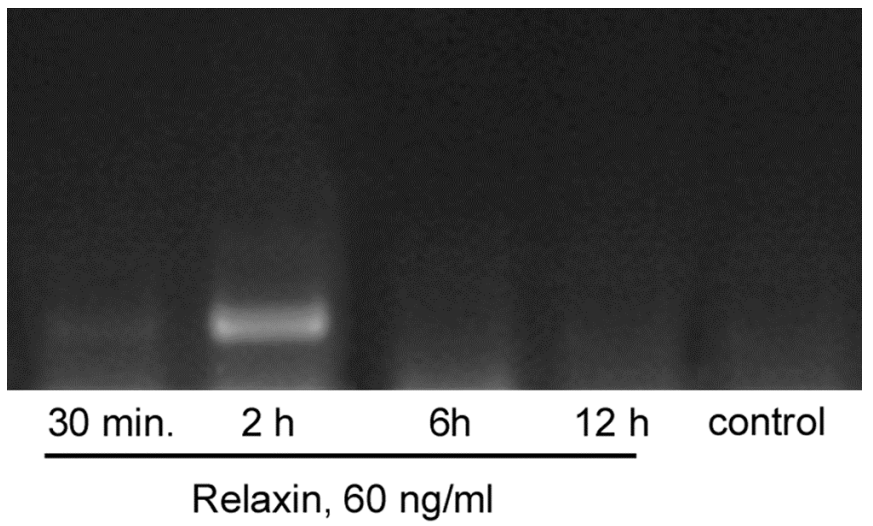

Fig. (3). Time-course of TNF- $\alpha$ PCR amplification products upon stimulation of RCE cells with relaxin at the noted concentration.

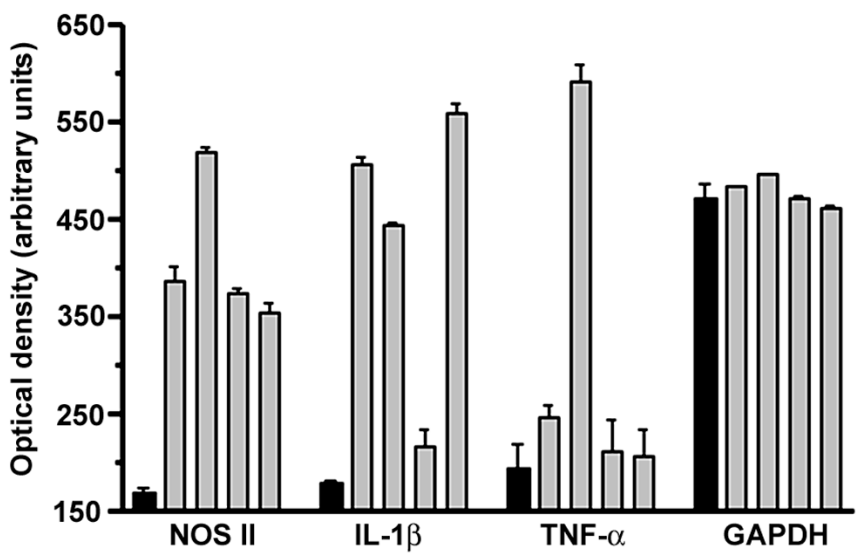

Fig. (4). Densitometric analysis of PCR bands for the expression of the noted genes. Black bars: untreated RCE cells; gray bars: RCE cells treated with $60 \mathrm{ng} / \mathrm{ml}$ relaxin for (left to right): $30 \mathrm{~min}$., $2 \mathrm{~h}, 6$ $\mathrm{h}, 12 \mathrm{~h}$.

assayed, the possibility that IL- $1 \beta$ and/or TNF- $\alpha$ may account, at least in part, for the effect of relaxin on NOS II expression could not be ruled out. Therefore, RCE cells were stimulated with relaxin for $2 \mathrm{~h}$ in a medium containing neutralizing anti- IL-1 $\beta$ and/or anti-TNF- $\alpha$ antibodies. Of note, even in the presence of the noted anti-cytokine antibodies, relaxin retained the ability to induce NOS II transcripts and to stimulate the endogenous generation of $\mathrm{NO}$, as indicated by measurement of the levels of nitrites, the stable endproducts of NO, in the cells' conditioned medium (Fig. 5AC). As expected, nonimmune goat serum substituted for the anti-cytokine antisera did not change the effect of relaxin on NOS II mRNA (data not shown).

\section{DISCUSSION}

The current findings indicate that relaxin, at the concentration of $60 \mathrm{ng} / \mathrm{ml}$ that has been proven adequate to upregulate NOS II in endothelial cells $[12,13]$, induces a prompt, long-lasting expression of NOS II mRNA and protein by RCE cells. This effect appears to depend on a direct action of the intracellular relaxin signaling pathway on NOS II gene, likely mediated by specific nuclear transcription factors such as NF- $k \mathrm{~B}$, as previously reported [11-13]. In the 
meantime, relaxin also increases the transcription of IL-1 $\beta$ and, at a lesser extent, TNF- $\alpha$, but these cytokines are not required to mediate the stimulatory effect of relaxin on NOS
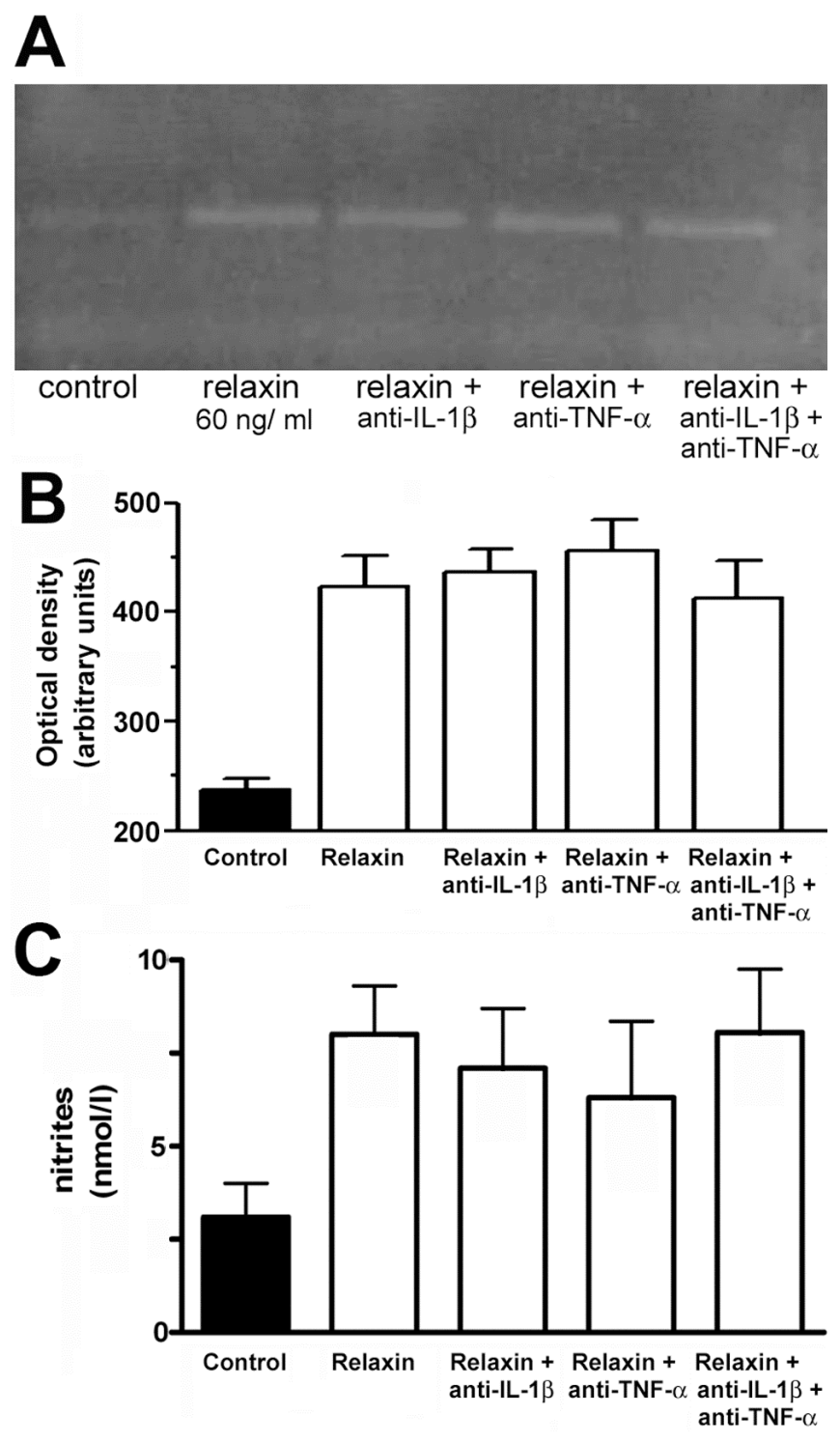

Fig. (5). (A) NOS II PCR amplification products in RCE cells, untreated (control) and treated with relaxin $(60 \mathrm{ng} / \mathrm{ml}, 2 \mathrm{~h})$ in the absence or presence of the noted neutralizing anti-cytokine antibodies. (B) Densitometric analysis of the PCR bands. (C) Nitrite amounts in the conditioned medium of RCE cells in the above experimental conditions.

II gene expression. Thus, it is conceivable that IL-1 $\beta$ and TNF- $\alpha$ expression may be the consequence of the activation by relaxin of transcription factors shared by NOS II and cytokines, such as NF- $k \mathrm{~B}$.

It should be noted that relaxin is the specific ligand of $G$ protein-coupled receptors, chiefly RXFP1, also expressed by blood [8]. It is tempting to speculate that, through activation of $\mathrm{G}_{\mathrm{s}}$ proteins and adenylate cyclase, relaxin may up-regulate the activity of protein kinase A (PKA) [18] which, in turn, may phosphorylate and inactivate $\mathrm{IkB}-\alpha$, the inhibitor subunit of the transcription factor NF- $\kappa B$, thus allowing NF$\kappa \mathrm{B}$ to translocate into the nucleus and to promote the expres- sion of NOS II [19]. The involvement of NF- $\kappa B$ in the response of RCE cells to relaxin is also indicated by our previous observation that NOS II induction by relaxin is suppressed by dexamethasone, a well known NF- $\mathrm{BB}$ inhibitor [12].

These findings may have important pathophysiological implications. In fact, evidence has been provided that NOS II, besides being up-regulated in the inflammatory process in response to pro-inflammatory cytokines [20], may also function as a "constitutive" enzyme in some cell types under physiological conditions $[11,21]$. Once synthesized upon the action of different inducers, NOS II is active for long times and generates large amounts of NO that can have beneficial effects, such as antiatherogenic and antiapoptotic actions [22]. At variance with pro-inflammatory cytokines, which lead to massive NOS II induction and consequent generation of harmful NO levels, relaxin could up-regulate NOS II in RCE cells within a physiologic range by an cytokineindependent pathway. In this way, relaxin could exert a broad spectrum of cardiovascular protective functions of endothelial-derived NO, which include the reduced expression of chemokines and adhesion molecules, as well as the inhibition of smooth muscle cell proliferation in the coronary vascular wall [reviewed in 23-25). In this context, relaxin may afford significant protection against cardiovascular ischemic disease, in agreement with the results of our previous studies in animals subjected to ischemia and reperfusion $[10,26,27]$. Of note, in the above studies, relaxin was also found to significantly decrease neutrophil extravasation into the damaged myocardium [26,27], an effect that can be ascribed to reduced neutrophil adhesion to the coronary endothelium mediated by increased generation of NO by the endothelial cells [28].

\section{ACKNOWLEDGEMENTS}

The authors gratefully acknowledge Dr. O. David Sherwood, Dept. of Molecular and Integrative Physiology, University of Illinois at Urbana-Campaign, who provided purified porcine relaxin as a gift. This work was supported by funds from the University of Florence, Italy.

\section{REFERENCES}

[1] Bani D. Relaxin, a pleiotropic hormone. Gen Pharmacol 1997; 28: 13-22.

[2] Sherwood OD. Relaxin's physiological roles and other diverse actions. Endocr Rev 2004; 25: 205-34.

[3] Nistri S, Bani D. Relaxin in vascular physiology and pathophysiology: possible implications in ischemic brain disease. Curr Neurovasc Res 2005; 2: 225-34.

[4] Dschietzig T, Bartsch C, Baumann G, Stangl K. Relaxin - a pleiotropic hormone and its emerging role for experimental and clinical therapeutics. Pharm Ther 2006; 112: 38-56.

[5] Samuel CS, Du XJ, Bathgate RAD, Summers RJ. Relaxin' the stiffened heart and arteries: the therapeutic potential for relaxin in the treatment of cardiovascular disease. Pharm Ther 2006; 112 : 529-52.

[6] Nistri S, Bigazzi M, Bani D. Relaxin as a cardiovascular hormone. Physiology, pathophysiology and therapeutic promises. Cardiovasc Hematol Agents Med Chem (CHA-MC) 2007; 5: 101-8.

[7] Osheroff PL, Ho W. Expression of relaxin mRNA and relaxin receptors in postnatal and adult rat brain and hearts. J Biol Chem 1993; 268: 15193-15199.

[8] Hsu SY, Nakabayashi K, Nishi S, et al. Activation of orphan receptors by the hormone relaxin. Science 2002; 295: 671-673. 
[9] Bani Sacchi T, Bigazzi M, Bani D, Mannaioni PF, Masini E. Relaxin-induced increased coronary flow through stimulation of nitric oxide production. Br J Pharmacol 1995; 116: 1589-94.

[10] Masini E, Bani D, Bello MG, Bigazzi M, Mannaioni PF, Bani Sacchi T. Relaxin counteracts myocardial damage induced by ischemia-reperfusion in isolated guinea pig hearts: evidence for an involvement of nitric oxide. Endocrinology 1997; 138: 4713-20.

[11] Bani D, Failli P, Bello MG, et al. Relaxin activates the L-argininenitric oxide pathway in vascular smooth muscle cells in culture. Hypertension 1998; 31: 1240-7.

[12] Failli P, Nistri S, Quattrone S, et al. Relaxin up-regulates inducible nitric oxide synthase expression and nitric oxide generation in rat coronary endothelial cells. FASEB J 2002; 16: 252-4.

[13] Quattrone S, Chiappini L, Scapagnini G, Bigazzi B, Bani D. Relaxin potentiates the expression of inducible nitric oxide synthase by endothelial cells from human umbilical vein in in vitro culture. Mol Hum Reprod 2004; 10: 325-30.

[14] Xie QW, Kashiwabara Y, Nathan C. Role of transcription factor $\mathrm{NF}-\mathrm{KB} / \mathrm{Rel}$ in induction of nitric oxide synthase. J Biol Chem 1994; 269: 4705-8.

[15] Singh S, Aggarwal BB. Activation of transcription factor NF-kappa $\mathrm{B}$ is suppressed by curcumin (diferuloylmethane) $\mathrm{J}$ Biol Chem 1995; 270: 24995-25000.

[16] Baeuerle PA, Henkel T. Function and activation of NF- $\mathrm{kB}$ in the immune system. Annu Rev Immunol 1994; 12: 141-179.

[17] Nistri S, Mazzetti L, Failli P, Bani D. High-yield method for isolation and culture of endothelial cells from rat coronary blood vessels suitable for analysis of intracellular calcium and nitric oxide biosynthetic pathway. Biological Procedures Online 2002; 4: 32-7.

[18] Kim NY, Pae HO, Kim YC, et al. Pentoxifylline potentiates nitric oxide production in interleukin-1 beta-stimulated vascular smooth muscle cells through cyclic AMP-dependent protein kinase A pathway. Gen Pharmacol 2002; 35: 205-11

[19] Nistri S, Bani D. Relaxin receptors and nitric oxide synthases. Search for the missing link. Reprod Biol Endocrinol 2003; 1: 5 .

[20] Kaku Y, Nanri H, Sakimura T, Ejima K, Kuroiwa A, Ikeda M. Differential induction of constitutive and inducible nitric oxide synthases by distinct inflammatory stimuli in bovine aortic endothelial cells. Biochim Biophys Acta 1997; 1356: 43-52.

[21] Guo FH, De Raeve HR, Rice TW, Stuehr DJ, Thunnissen FB, Erzurum SC. Continuous nitric oxide synthesis by inducible nitric oxide synthase in normal human airway epithelium in vivo. Proc Natl Acad Sci USA 1995; $92:$ 7809-13.

[22] Wang BY, Ho HK, Lin PS, et al. Regression of atherosclerosis: role of nitric oxide and apoptosis. Circulation 1999; 99: 1236-1241.

[23] Förstermann U, Closs EI, Pollock JS, et al. Nitric oxide synthase isozymes: characterization, molecular cloning and functions. Hypertension 1994; 23: 1121-31.

[24] Moncada S, Higgs EA. Molecular mechanisms and therapeutic strategies related to nitric oxide. FASEB J. 1995; 9: 1319-30.

[25] Gibbons GH, Dzau VJ. Molecular therapies for vascular diseases. Science 1996; 272: 689-93.

[26] Bani D, Masini E, Bello MG, Bigazzi M, Bani Sacchi T. Relaxin protects against myocardial injury caused by ischemia and reperfusion in rat heart. Am J Pathol 1998; 152: 1367-76.

[27] Perna AM, Masini E, Nistri S, et al. Novel drug development opportunity for relaxin in acute myocardial infarction. evidences from a swine model. FASEB J 2005; 19: 1525-7.

[28] Nistri S, Chiappini L, Sassoli C, Bani D. Relaxin inhibits lipopolysaccharide-induced adhesion of neutrophils to coronary endothelial cells by a nitric oxide-mediated mechanism. FASEB J 2003; 17: 2109-11.

(C) Nistri et al.; Licensee Bentham Open.

This is an open access article distributed under the terms of the Creative Commons Attribution License (http://creativecommons.org/licenses/by/2.5/), which permits unrestrictive use, distribution, and reproduction in any medium, provided the original work is properly cited. 